\title{
GENERATION $X$, INTERGENERATIONAL JUSTICE AND THE RENEWAL OF THE TRADITIONING PROCESS
}

\author{
Authors: \\ Cory L. Seibel ${ }^{1,2}$ \\ Malan $\mathrm{Nel}^{2}$

\section{Affiliations:} \\ ${ }^{1}$ Mennonite Brethren \\ Biblical Seminary, Fresno \\ Pacific University, United \\ States \\ ${ }^{2}$ Department of Practical \\ Theology, University of \\ Pretoria, South Africa
}

\section{Correspondence to:} Cory Seibel

email:

cory.seibel@fresno.edu

\section{Postal address:}

1717 South Chestnut

Avenue, Fresno, California

93702, United States

\section{Keywords:}

Generations; Gen X; tradition; postmodernism; intergenerational justice; church renewal

\section{Dates:}

Received: 09 Sept. 2009

Accepted: 05 May 2010

Published: 04 Oct. 2010

How to cite this article: Seibel, C.L \& Nel, M., 2010, 'Generation X, intergenerational justice and the renewal of the traditioning process', HTS Teologiese Studies/ Theological Studies 66(2), Art. \#876, 7 pages. DOI: 10.4102/hts.v66i2.876

\section{This article is available at:} http://www.hts.org.za

\section{Note:}

This article is a reworked version of Dr Cory L. Seibel's DPhil dissertation, 'Intergenerational reconciliation and justice as essential dimensions of missional renewal in the postmodern transition', submitted to and accepted by the University of Pretoria in 2009, with Prof. Dr Malan Nel as supervisor.

(C) 2010. The Authors. Licensee: OpenJournals Publishing. This work is licensed under the Creative Commons Attribution License.

\section{ABSTRACT}

The church has the task of transmitting its faith tradition from one generation to the next. In the transition to postmodernity, many established congregations have proven to be ineffective at this traditioning process in relation to Generation X (Gen X), the first postmodern generation. The reasons for the ineffectiveness are complex. This article focuses on two key factors that contribute to the problem: the reduction of the church's tradition to its particular expression within the culture of modernity and the marginalisation experienced by Gen Xers within many established churches. The latter has prevented them from becoming effective bearers of the church's tradition. If this trend is to be reversed, churches should succeed in renewing their traditions in a way that is meaningful in a postmodern context. The challenge will be to overcome the dynamics of reductionism and marginalisation. In developing the argument, the jubilee themes of 'return' and 'release' are applied to the intergenerational dynamics of established congregations. The article concludes that local congregations should embrace a renewed commitment to intergenerational justice, which will encourage equity between the generations.

\section{INTRODUCTION}

Since the earliest days of the Christian movement, the intergenerational nature of the local church has been an important aspect of its existence. As Harkness (1998) insists,

Ever since the development of Christian faith communities in the post-Pentecost era of Christianity, there has been a consciousness that such communities need to encourage and embody a genuine intergenerationalism.

(Harkness 1998:41)

However, the precedent for viewing the church as an intergenerational community is evident not only as we look back retrospectively, but also as we look forward expectantly. As an eschatological community called to bear witness to the 'already, but not yet' reign of God, the church must strive to practice what the New Testament frequently describes as 'patient endurance' (Barrett 1998:124). This challenge of enduring faithfully can be taken to mean that the church should strive to sustain its witness 'throughout all generations' (Eph 3:21). Indeed, in reflecting upon the practical implications of the call to 'patient endurance', Peterson (1989:47) suggests that, '[i]f we are going to learn a life of holiness in the mess of history, we are going to have to prepare for something intergenerational and think in centuries' (emphasis added ).

The importance of the church's intergenerational calling presents it with the challenge of perpetuating its faith tradition from one generation to the next. Leith $(1990: 34,36)$ views this as involving a process of 'traditioning', which entails the incorporation of 'each new person and generation' into the community of faith. The church, as a bearer of tradition, endeavours to provide a setting in which individuals might gain a vital experience of faith and an authentic sense of identity and in which successive generations might be incorporated into the Christian tradition (Bass 1994:173-175, 180). Within this process, the congregation does not relate to its tradition merely as preserver and participant. Rather, it actively influences the shape of that tradition as it appropriates and expresses it within its particular time and place (Bass 1994:185). The process of traditioning is dynamic, with change as an inherent characteristic and asset. The congregation must engage in a reflexive cultural task of 'fluid traditioning', which necessitates that its members understand themselves not only as 'receivers' of tradition, but also as makers of future tradition (Butler Bass 2004:40-50).

If the intergenerational traditioning process is to be accomplished effectively, this requires at least two things of the congregation. Firstly, the relevance of the church's mission and message must be rediscovered and re-appropriated in cultural forms that speak to the members of each new generation (Kraft 2005:224). Lytch $(2004: 58-59,211)$ has found that at least two factors play a prominent role in solidifying the loyalty of young people to a particular religious tradition. These are, (1) consistent religious socialisation and (2) meaningful religious experience. However, the faith embraced by each new generation needs to be faith that can be understood and expressed in terms of their specific subculture (Kraft 2005:67). Thus, the socialisation and experience offered to the members of each rising generation must connect with their cultural reality. As Merritt (2007:84) expresses, '[a]s new generations gather in a church, vital congregations learn to adapt their customs while keeping their traditions.'

Secondly, the congregation should be willing to empower each rising generation with the freedom to make their distinctive mark upon the shape of that tradition. Kraft (2005:247) puts it as follows: 'It is crucial that each new generation and people experience the process of producing in its own cultural forms an appropriate church vehicle for the transmission of God's meaning.' In essence, the continual process of fluid traditioning must be seen as having an intergenerational trajectory (Carroll \& Roof 2002:213). If a congregation's members truly consider their corporate witness of primary importance and intend for it to endure beyond their own life span, they must be willing to set aside their personal preferences about church to enable 'a new ethos to be born' (Thompson 2003:162). 


\section{A CRISIS OF TRADITIONING}

\section{Evidence of a crisis}

In recent years, much attention has been given to exploring the postmodern shift through which society has been journeying. While major paradigm changes invariably come to bear on all sectors of society, such shifts impact the various generations who live through them differently. This is by virtue of the fact that each generation experiences the movement of time through its own distinct 'age location in history' (Strauss \& Howe 1992:48). Generation X (Gen X, born between 1965 and 1981) provides a clear example of this concept of 'age location in history.' The formative experience of this generation is so closely linked with the influence of postmodernity that it must be described as the first 'postmodern generation' (Long 1997:2).

Unfortunately, as we now examine the behaviour of Gen Xers as adults, it is evident that many established churches have failed in transmitting their faith traditions to this first postmodern generation. Recent empirical studies have generated compelling evidence to demonstrate the relative absence of this first postmodern generation from many established churches (Wuthnow 2007:51-53). Many commentators express grave concern toward this trend. Gibbs (2000:190, 230), for example, finds it troubling that 'a disturbingly large number of Gen Xers has given up on the church ... For the most part they are not looking to Christian churches to meet their spiritual needs.' Many Gen Xers actually choose to classify themselves as former Christians (Schroeder 2002:55-61). Millions of these unchurched adults now have no interest in church. To these people, embracing church would be counter-cultural and even counter-intuitive. These realities seem to suggest rather strongly that, from the time of the Gen Xer formative years, something has gone terribly wrong with the intergenerational traditioning process within many local churches. I would like to explore two factors that have contributed to the breakdown in the traditioning process evident among the members of this generation.

\section{The reduction of tradition}

Firstly, I have stated above that, in order for a church to pass its tradition from one generation to the next, the relevance of the church's message must be re-appropriated in cultural forms that speak to the members of rising generations (Kraft 2005:224). However, this often is easier said than done. Rendle (2002:2) notes that religion is by nature 'highly resistant to change.' As churches pass their traditions from generation to generation, 'rituals, ceremonies, and religious texts represent a tie to the past, a connection to a transcendent history.' Thus, efforts to respond in an innovative manner to generationally borne changes in the church's cultural context are understood to place at risk the 'plausibility' that causes the church to be viewed as legitimate by its adherents. Indeed, long-term members tend to view the plausibility of their church as being tied to its ability to preserve those elements that they believe constitute an 'ancient' tradition.

In fact, this concern for faithfulness is often precisely what leads churches to cling to an errant understanding of tradition. This is evident in Guder's (2000:100) exposition of the historical tendency toward reductionism within the church. Guder explains that, over time, the faith communities formed within a given culture tend to reduce their understanding of the gospel to that which has resulted from the interface of gospel and culture in that context. This 'reduced' understanding of the faith becomes problematic when 'the sinful human desire to control begins to do its work' (2000:100). Guder further argues that '[w]e are constantly tempted to assert that our way of understanding the Christian faith is a final version of Christian truth' and thereby 'enshrine one cultural articulation of the gospel as the normative statement for all cultures.'

While this tendency may be rooted in noble intentions, the formula of reduction and control, which Guder (2000:230-231) describes as reductionism, poses a significant risk to the integrity of the church's true calling. When the church becomes bound by a reductionistic understanding of its tradition, its missionary impulse is compromised (Shenk 1995:48) and it loses sight of the extent to which its life and structure is culturally determined (Snyder 1996:136). Furthermore, this can have a profoundly negative impact upon the experiential vitality of the church's tradition. As Kraft (2005:297) notes, 'whenever and wherever the church has turned from being venturesome and retreated into static forms of expression it has lost its dynamic.'

This reductionistic tendency poses significant challenges to the integrity of the intergenerational traditioning process. As Kraft (2005) notes,

$[m]$ ost often the forms of the group in power have simply been imposed upon any new receiving group (whether the children of the group in power or the members of a different society or subsociety).

(Kraft 2005:224)

He adds, '[f]aith alone is not enough for [the group in power]. It has to be faith as understood by and expressed in terms of their particular subculture' (2005:267). As we might expect, this prevents the members of rising generations from responding to God directly 'in terms of their own subcultural structures' (2005:265). Instead, they are expected to convert to a cultural form in which previous generations are comfortable. Such an approach threatens to foster nominalism (2005:266). Some within rising generations may choose simply to abandon this expression of 'domesticated' Christianity by leaving the church altogether (Wright \& Creasy Dean 2004:158).

The fact that many established churches today are struggling to respond to the cultural changes associated with the postmodern transition is evidence that this reductionistic dynamic is at work in their midst. The reductionistic expression of the faith common in many established American churches is decidedly modern. This approach to the faith arguably reached the pinnacle of its expression during the 1950s, a period in which established churches across America flourished. Butler Bass (2004:78) describes the typical congregation of this era as an 'accidental church,' one that did not perceive itself as needing to relate to its context with missional intentionality. These congregations were not bad places, she insists, but rather dynamic, effective, growing churches that met the needs of people during that particular passage in the nation's history (2004:95). However, it was precisely because of the success of these congregations that they lost 'the capacity to imagine church being different than how they experienced it and, essentially, froze tradition in its tracks.'

Owing to the fact that modern assumptions have been woven so deeply into the core beliefs of these churches, many congregations have proven to be ill prepared to respond creatively to the cultural changes associated with the postmodern transition (Drane 2000:114). As a result, these churches also have proven ineffective at transmitting their faith traditions to the first generation of postmodern adults. The members of this generation were brought up with less exposure to religious institutions than the generations that preceded them (Carroll \& Roof 2002:25). Thus, the influence of the church's intergenerational traditioning practices was absent from the lives of many Gen Xers. However, because of the disconnection between the church's practices and the cultural realities of this generation, even many of the Gen Xers who were raised within the church have rejected institutional Christianity. As Moore (2001:133-134) asserts, 'too many of our traditional church practices put them off.'

Older members are sometimes guided by a sincere desire to see younger generations have the same spiritual experiences that they found meaningful (Whitesel \& Hunter 2000:163). Nonetheless, Moore (2001:133-134) credits a fundamental disconnection between Gen Xers's desire for an experiential basis for spirituality and the traditional approach to the faith 
employed in many modern churches as being one reason why, at the time of his writing, there were one-third fewer converts among Gen Xers than there had been among Boomers at the same period in their generational life cycle. As Schroeder (2002:55) proclaims, speaking on behalf of post-Christian Gen Xers, '[e]xperience-spiritual experience-was exactly what we did not get at church'. In essence, it seems that the church's key objective of serving as a context for religious socialisation and religious experience was not effectively achieved in the lives of so many members of this generation.

Nonetheless, many churches continue to operate as though little of significance has occurred. Many congregations continue to function as if this were the middle of the 20th century, rather than the beginning of the 21st (Kew 2001:33). Older members sometimes mistakenly assume that the differences between themselves and younger generations are merely a matter of 'maturity' that will eventually be resolved and thus do not require significant changes (Whitesel \& Hunter 2000:163). As a result, the limited growth that does occur in these churches is usually by transfer growth from churchgoers moving into the community or by 'church hoppers'. While these traditional church congregations do continue to show some evidence of being multigenerational, 'they are composed almost entirely of long-established churchgoing Christians and their families' (Benke \& Benke 2002:88).

In essence, many established churches seem to have chosen practices and programmes rooted in a reductionistic approach to the faith over the option of responding adaptively to cultural change (Carroll \& Roof 2002:137). Many of these 'traditional' patterns are not particularly old. As Beaudoin (1998:154) notes, much of what is called 'tradition' within our contemporary context is really an innovation little older than our grandparents'. Nonetheless, these practices have come to be characterised by predictability and control, rather than life. As a result, they no longer are proving meaningful to many young adults (Butler Bass 2004:48). Thus, as McManus (2001:31) potently asserts, many churches, while keeping their traditions, have lost their children.

\section{Intergenerational power struggles in the church}

A sizeable minority of Gen $X$ adults do remain involved in many established congregations (Wuthow 2007:2). However, though the members of this generation offer a knowledge of the culture of postmodernism that could be of service to their congregations and though they are actively engaged in significant cultural production in other areas of life (Flory \& Miller 2007:202), these young adults frequently are disempowered and devalued within the congregation (Conder 2006:39; Whitesel \& Hunter 2000:19-20). As Carroll and Roof $(2002: 138,207)$ assert, younger people frequently are welcome to participate only on the terms dictated by their elders, rather than on the basis of a willingness on the part of the elder generations to adapt or to negotiate differences across generational lines. In essence, the second dynamic of the traditioning process, that is, the empowerment of each succeeding generation to impact the shape of the tradition, is being hindered.

In far too many situations, Gen Xers have simply suffered the impact of the 'intergenerational antipathy' that exists within many churches (Hilborn \& Bird 2003:162). Gen Xers grew up in churches dominated by the power struggle between Boomers and their elders in the decades following the 1960s (Codrington \& Grant-Marshall 2004:243). In many congregations, this battle over who would exercise authority and control (Carroll \& Roof 2002:4) was manifested in 'win/lose' struggles surrounding issues such as the style of music employed in worship (Rendle 2002:112; Schaller 1999:17, 133). Codrington and Grant-Marshall (2004:234), assert that, as a result of these sorts of struggles, ' $t$ t]here are few areas in our lives where the generation gap is greater than it is in the church.'
Indeed, in the wake of a protracted period of struggle, many pre-Boomer elders within the church demonstrate reluctance toward relinquishing their hold upon the congregation's life. These generations place a high value on tradition and desire for the church to emphasise their heritage and opinions (Whitesel \& Hunter 2000:75). At times, they are resistant to change because they do not understand why cherished traditions need to be altered, or because they fear being disempowered in decisions about changes within the congregation (Mead 1991:36). After engaging in painful church battles with their Boomer children, many within these generations are afraid of being 'forced out' (Whitesel \& Hunter 2000:23-24).

Thus, even in their retirement years, many pre-Boomers continue to tighten their grip on their positions of influence (Merritt 2007:91). These elders tend to

have an authoritarian approach to leadership and use bureaucratic structures to enforce their own style on the rest of the church, relying on positional authority and claims of biblical truths, rather than on relationships and winning people over to their way of thinking.

(Codrington \& Grant-Marshall 2004:239)

However, this is problematic for Gen Xers who prefer 'flatter' organisational processes and tend not to be interested in the modern hierarchical structures that many churches employ (Long 1997:154), who want to be empowered to become a meaningful part of the community (1997:156), and who prefer a more informal and relational approach to organisational life.

The prominence of Boomers within established churches also makes it difficult for Gen Xers to be able to contribute meaningfully and equitably. The Boomers are a generation that has grown accustomed to being in charge. As Barna (2004) explains,

$[u]$ nfortunately, we are not good at sharing ... And we are driven by the one value that defines us and on which we are willing to squander our money: power. We believe so deeply in our decisionmaking capacity, and we enjoy the control and perks of calling the shots so much, that we have no intention of relinquishing that power, regardless of traditions, expectations, reason or future interests.

(Barna 2004)

In many congregations, the prediction that Drury (1996) offered more than a decade ago has been realised to the detriment of Gen Xers:

The Xers will be crowded out, marginalized, ignored. Most boomer ministers don't even know what busters want. Or care. They are tired of changing. Like old warriors they now preach peace once they've moved in the army of occupation.

(Dury 1996)

In reality, many Boomer leaders have not developed a concern for mentoring Xers or for providing them meaningful opportunities to develop their leadership skills (Codrington \& Grant-Marshall 2004:244).

Many Gen X Christians have chosen to respond to the marginalisation they have experienced within established churches by simply walking away. Gen Xers are keenly sensitive to issues of institutional injustice (Bourne 1997:103). As Ritchie (1995:39) explains, this sensitivity is rooted in the reality that 'Xers experienced, and were required to assume, an independence in household responsibility unmatched by any previous generation.' Essentially, because the members of this 'latchkey' generation grew up accustomed to making independent decisions, many came into adulthood expecting to be able to have a say in the projects with which they are involved (Celek \& Zander 1996:32). In addition, as I have mentioned above, Gen Xer attitudes toward institutional structures have been influenced by the postmodern 'flattening' of authority. As Long (1997:156) suggests, once they are 'in the door', they want 
to be empowered to become a meaningful part of the community. Where Gen Xers sense that their contribution is not welcomed or appreciated, they may simply withhold or withdraw their participation (Long 1997:154).

Because of these generational values, Gen Xers have tended not be interested in entering into the power struggle between the generations within the church (Codrington \& Grant-Marshall 2004:245). Instead, they have chosen simply to respond with 'widespread flight' (Barna 2004). As Hammett and Pierce (2007:35) note, 'in many churches nearly everyone under forty has given up being actively involved in the church.' As I have suggested above, this failure of the traditioning process now constitutes a significant crisis in many established churches. These churches have come to be characterised by a widening inability to connect with a changing culture. As a result, they are at risk of losing touch with what form the pursuit of meaning is taking in the postmodern world (Lynch 2002:120-121). These churches

simply have not continued to reach even [their] own adult children who are now bearing their own children, let alone reach the significant number of younger families who are part of the general population.

(Rouse \& Van Gelder 2008:59)

Thus, the capacity of these churches to endure faithfully is being seriously jeopardised.

\section{TOWARD THE RENEWAL OF THE TRADITIONING PROCESS}

\section{The need for Generation $X$}

There is a clear need for established churches to experience the renewal of their effectiveness in traditioning the faith within the emerging postmodern context. However, in order for this to occur, they will need to move beyond the limitations of the reductionistic expression of the Christian tradition that has arisen in the modern era. The process of re-traditioning within established churches must now be understood as having a missional orientation. As Rendle (2008) suggests, the process of 'allowing new forms and practices that are fully embedded in ancient truth' to reshape the congregation's life

in a way that is sensitive to the eyes, ears, and hearts of those to whom the faith is to be given ... is a missionary task-holding the unchanging truth but shaping it to be understood in the present and changing culture.

(Rendle 2008:60)

In essence, the first dynamic of the traditioning process (i.e. reshaping the faith in a way that is meaningful to new generations of church members) must be renewed among the first postmodern generation of adults and their children.

However, in order for this to be possible, the second dynamic of the traditioning process (i.e. empowering succeeding generations to impact the shape of the tradition) must also be renewed. In this regard, the immense importance of reengaging the members of the marginalised Gen X must be recognised. This generation has the potential to play an important role in helping local congregations to respond to the changes associated with the emergence of a postmodern world. Kitchens (2003:36) asserts that established churches already have the resources they need to begin recast its faith and practices in ways that are meaningful for a new culture. Prominent among these resources is the presence of postmodern young adults within the church. The more that the insight of postmodern young adults is taken into consideration, suggests Kitchens (2003:76), 'the more clarity the church as a whole will have about the boundary between its worldview and values and those of the surrounding culture.' Owing to their chronological proximity to the postmodern transition, Gen Xers should be recognised as a 'catalyst' and 'hinge' generation, one that could help the church to deal with the challenges surrounding the transition beyond modernity (Kew 2001:26-27, 126).

\section{The need for intergenerational justice}

An acknowledgement of the importance of Gen Xers does not solve the fact that this generation of adults frequently is hindered from influencing the bearing of tradition and from participating equitably in congregations' organisational life. Unless established churches choose to address some of the most fundamental problems that Gen Xers have with the church, they are not likely to be any more effective in engaging the members of this generation than they have been in the past. Certainly, the issues contributing to the breakdown in relationship between Gen $X$ and established churches extend beyond the scope of what I am exploring here. Nonetheless, I would like to assert that one crucial factor that must be addressed is the issue of intergenerational justice.

Max DePree (1997:61) posits that justice is an important issue in contemporary non-profit organisations: '[j]ustice is high on most people's list of ideas that tell us the way life ought to be ... [J]ustice begins with the opportunity to make a meaningful contribution.' DePree continues by suggesting that justice within organisational settings entails equity. DePree (1997:63, 156) suggests that equity entails being treated fairly and having access because it is a characteristic of healthy communities. Unfortunately, many Gen Xers do not feel as though the church is a place in which they have been afforded the sort of fairness and access that would enable them to make a meaningful contribution. As I have noted above, this is an affront to the values of this generation.

In seeking to describe this problem further, I would like to employ two social-scientific categories: 'power' and 'capital'. Firstly, Weber's (1978:53) classic definition of power describes it as the chances which a [person] or group of [persons] have to realize their will in a communal activity, even against the opposition of others taking part in it.' As I have suggested above, Gen Xers have been left with the impression that their voices have been disempowered within the congregation. Secondly, we can observe that the inequitable distribution of power has caused Gen Xers to be affected by an imbalanced appropriation of 'human capital' within the congregation. This term

consists of the ways that persons apply their own experience, skills, energy, and interests toward certain activities and programs, with the expectation that such an 'investment' will pay 'dividends' to them.

(Thompson 2003:101)

Gen Xers have faced limits in the degree to which they are able to bring their gifts, experiences and insight to bear on the way in which their faith tradition is expressed. Sadly, some of Gen $X^{\prime}$ 's elders have seemed to be more concerned with their own dividends, in relation to their tradition, than with making capital investments in future generations.

Another author whose work provides a useful lens through which can understand the experiences of Gen Xers in many established congregations is the ethicist John Rawls (1999:251-258). Rawls has written about the issue of justice in regard to the intergenerationally just distribution of resources within society, arguing that:

Each generation must not only preserve the gains of culture and civilization, and maintain intact those just institutions that have been established, but it must also put aside in each period of time a suitable amount of real capital accumulation.

(Rawls 1999:252)

In essence, Rawls is advocating for the choice of the generations presently in control to allocate resources for the sake of the continued advancing of society within future generations. Rawls (1999:257) posits that it is not acceptable for the dominant contemporary generations to justify prioritising its own interests 
at the expense of future generations. According to Rawls, this has significant implications for the ethical choices that each generation makes in relation to those that follow it.

I would like to assert that many established churches have failed to exemplify a commitment to intergenerational justice. Employing the language of DePree and Rawls, this can be restated as follows: there exists a lack of equity and, more specifically, a lack of the equitable distribution of the resources of power and human capital among the generations of which the congregational is composed. Older members of the church have sought to grasp onto power and position in a manner that prevents Gen Xers from assuming leadership or participating fully in decision making structures. As we have seen many times, this has simply led to the withdrawal of disillusioned Gen Xers from congregational life. In turn, the result of this situation poses an even more egregious inequity in that the love and grace of Christ is essentially being withheld from postmodern Gen Xers and their children, who remain at considerable cultural distance from the church's traditional forms.

In the face of this unfortunate reality, it is crucial to note that God desires for justice to be embodied within the concrete social reality of the church. DeGruchy (2002:54) notes that, for the community born out of the redemptive work of God in Christ, ' $[t]$ o be reconciled to God and to do justice are part and parcel of the same process.' Through the way that they share life together, members of the church are called to manifest a foretaste of the just reality that Christ will bring about fully in the future (Koester 2004:311). One crucial implication of this is that the church is called to be a community of equity (DeYoung 1995:174). As Koester (2004) notes, members of the new community have been called

to establish equality and justice in their own midst and to spread the message, the gospel, to as many people as they can, inviting them to join the new community of justice and love.

(Koester 2004:311)

Within the life of this community, the radical equity inaugurated by Christ should constitute the basis for members's ethical behaviour (2004:313).

The distribution and exercise of power is one facet of the community's life that is implicated in this theological vision. Law (1993:13) suggests that biblical justice is concerned with 'equal distribution of power and privilege among all people'. The church community is to exemplify a commitment to prioritising quality relationships over the possession of quantities of power (Brownson, Dietterich \& Harvey 2003:102). Indeed, within the Christian community, 'relationships of domination are not permitted' (Lohfink 1984:49). Instead, the Christian community is called to strive to make God's justice a present reality within its political and social organisation and functioning (Koester 2004:314).

How might this vision of justice be translated meaningfully into the life of those congregations in which a lack of equity has come to hinder the participation of Gen Xers? In answering this question, we must note that the restoration of equity within those settings where injustice is present is a significant biblical theme. Harris (1996:79) identifies the Old Testament imagery of the celebration of jubilee as a focal point in the scriptural witness related to this theme. As outlined in Leviticus 25:8-55, the year of jubilee

was to be a proclamation of liberty to Israelites who had become enslaved for debt and a restoration of land to families who had been compelled to sell it out of economic need sometime during the previous fifty years.

(Wright 2006:290)

This practice reflected within the nation of Israel what God desires in principle for all of humanity: 'broadly equitable distribution of the resources of the earth ... and a curb on the tendency to accumulation with its inevitable oppression and alienation' (Wright 2006:296). Properly understood, this was not simply a 'redistribution' of resources, but rather a 'restoration' (Wright 2006:297). The restoration that the jubilee was meant to achieve had two central thrusts: release and return.

The jubilee tradition continues to have relevance for Christians today because of the fact that Jesus appropriated the imagery of the jubilee in his announcement of the in-breaking reign of God and actually 'fulfilled' the jubilee that he proclaimed (Wright 2006:300-301). As Wright (2006:300) posits, '[t]he theological underpinning of the socioeconomic legislation of the jubilee is identical to that which undergirds the proclamation of the kingdom of God'. Within our contemporary context, this challenges us to adopt a commitment to exploring and establishing 'what belongs to whom and to return it to them' (Harris 1996:76). I would like to offer a brief exploration of the implications that this might have in relation to the lack of intergenerational equity in established congregations.

If we take seriously the jubilee theme of 'return', what insight might it provide for churches in which this inequity exists? The spirit of jubilee justice necessitates that established churches regain a proper perspective regarding whose resources are at stake within the life of the church. While we have appropriated social-scientific categories to describe the resources of power and capital within the church, we can affirm that the deeper spiritual realities these categories describe are fundamentally imparted to the congregation as God's gifts. For example, the true essence of the power at work within the church can be understood as coming from Holy Spirit who resides within every member of the body. Authority, therefore, 'is found neither in particular status nor in majority opinion. It is dispersed throughout the whole body through the illumination and empowerment of the Spirit' (Dietterich 1998:173-174). A serious commitment to the spirit of jubilee justice, thus, must challenge Gen X's elders to surrender or 'return' all inordinate claims upon the distribution of power and influence within the congregation to their rightful Lord. Indeed, they must be willing to foster a culture in which power is distributed more equitably among the generations and in which the first postmodern generation is thus empowered to contribute more fully in leadership and decision making processes.

The jubilee theme of 'release' also holds significant implications for the pursuit of intergenerational justice within established churches. The issue of human capital within the church is inextricably linked with the 'gifts of the Spirit' that the Apostle Paul demonstrates as playing an integral role in the upbuilding of the congregation (1 Cor 12). Far from being the possession of any individual, Paul explicitly explains that these gifts are distributed among the members of the body 'according to the grace given to us' (Rm 12:6). Dietterich (1998) reflects upon the practical implications of this:

Because all receive gifts to contribute to the common good, everyone enjoys the right and the obligation of participating authoritatively in decisions of faith and practice ... None is given advantage; all are equipped for service.

(Dietterich 1998:173-174)

If this perspective is taken seriously, the vision of jubilee justice should lead to the younger members of the community being liberated to participate equitably in the church's life as God intends. The gifts with which God has endowed the members of this generation need to be permitted to gain expression to the benefit of all.

Finally, the jubilee themes of return and release also confront the protective control of the tradition that often occurs within many congregations. MacIntyre (1984:222) has argued that a living tradition entails the continuous presence of an argument internal to that tradition regarding the goods with which it is concerned. As I have demonstrated in this article, within some established congregations, there no longer exists a willingness to entertain such an argument. These congregations must be reminded that 
the goods with which the Christian tradition is concerned find their centre in God's gracious gift, the transgenerational Good News of Christ. Thus, the spirit of jubilee justice should challenge members within the church to return any undue claims that they have made in relation to their tradition's essential goods, as these rightly belong to Christ himself. Furthermore, in light of what I have stated above, we can assert that the internal argument of which MacIntyre writes is one in which each generation must be empowered to participate. This means that Gen Xers, and those who come after them, must be released from the institutional dynamics that prevent them from influencing the traditions their churches hold dear. Indeed, they need to be granted the freedom to help shape the future of their respective traditions.

Having outlined these thoughts about the need for return and release within the intergenerational dynamics of established churches, I would like to briefly outline a number of practical ways in which these themes might gain expression within these congregations. These include:

- A commitment of older church members to view new generations not as competitors, but as collaborators in shaping the tradition.

- The commitment of older church members to share resources with Gen Xers and those who come after them.

- A willingness to listen to young adults and a commitment to empower and equip them to contribute actively to leadership and decision making processes.

- Granting Gen Xers and those who come after them the freedom to influence the shape of the congregation's tradition and even to nurture their own spiritual traditions.

- Adopting a 'discipline of dialogue' (DeYoung 1995:174) that encourages members of all generations to try to see things from one another's viewpoint. The commitment of church leaders to protect the elderly from victimisation in the process of reaching the young and through the willingness of Gen Xers to demonstrate respect and consideration toward their elders.

- The church's willingness to adjust their organisational structures to move from hierarchy to 'heir-archy' and from a culture of control to one of cooperation (Frost \& Hirsch 2003:21).

Through practical steps such as these, established churches can foster the spirit of jubilee justice among the generations of which they are composed and thus achieve a greater measure of intergenerational equity. This could provide a significant step in the right direction in helping these churches to experience renewed effectiveness in ministering in a changing world.

\section{CONCLUSION}

The possibility that Generation X, the postmodern 'hinge' generation, can be empowered to contribute to the unfolding intergenerational traditioning of the church's witness is a powerful prospect. As the church strives to embody justice in its shared life, it will exemplify something that is attractive and trustworthy to the sceptical, cautious members of this generation. In addition, the extraordinary testimony of a community committed to embodying intergenerational justice will bear witness to the world of God's in-breaking reign. Finally, as churches renew their commitment to the intergenerational traditioning process in relation to postmodern young adults, they also will be helped in renewing their capacity to 'endure faithfully' throughout generations to come.

\section{REFERENCES}

Barna, G., 2004, Gracefully passing the baton, viewed 07 February 2006, from http://www.barna.org

Barrett, L., 1998, 'Missional witness: The church as apostle to the world', in D.L. Guder (ed.), Missional church: A vision for the sending of the church in North America, pp. 110-141, Eerdmans, Grand Rapids.
Bass, D.C., 1994, 'Congregations and the bearing of traditions', in J.P. Wind \& J.W. Lewis (eds.), American congregations, vol. 2, New perspectives in the study of congregations, pp. 40-50, University of Chicago Press, Chicago.

Beaudoin, T., 1998, Virtual faith: The irreverent spiritual quest of Generation X, Jossey-Bass, San Francisco.

Benke, W. \& Benke, L., 2002, The generation driven church: Evangelizing boomers, busters, and millennials, Pilgrim Press, Cleveland.

Bourne, R.S., 1997, 'The two generations', in R.D. Thau \& J.S. Heflin (eds.), Generations apart: Xers versus Boomers versus the elderly pp. 95-105, Prometheus Books, Amherst.

Brownson, J.V., Dietterich, I.T. \& Harvey, B.A., 2003, StormFront: The good news of God, Eerdmans, Grand Rapids.

Butler Bass, D., 2004, The practicing congregation: Imagining a new old church, The Alban Institute, Herndon.

Carroll, J.W. \& Roof, W.C., 2002, Bridging divided worlds: Generational cultures in congregations, Jossey-Bass, San Francisco.

Codrington, G. \& Grant-Marshall, S., 2004, Mind the gap! Penguin, Johannesburg.

Conder, T., 2006, The church in transition: The journey of existing churches into the emerging culture, Zondervan, Grand Rapids.

DeGruchy, J.W., 2002, Reconciliation: Restoring justice, Fortress, Minneapolis.

DePree, M., 1997, Leading without power: Finding hope in serving communities, Jossey-Bass, San Francisco.

DeYoung, C.P., 1995, Coming together: The Bible's message in an age of diversity, Judson, Valley Forge.

Dietterich, I.T., 1998, 'Missional community: Cultivating communities of the Holy Spirit', in D.L. Guder (ed.), Missional church: A vision for the sending of the church in North America, pp. 142-182, Eerdmans, Grand Rapids.

Drane, J., 2000, Cultural change and biblical faith, Paternoster Carlisle.

Drury, K., 1996, Boomer nursing homes, viewed 12 April 2005, from http://www.drurywriting.com/keith/nursing.htm

Flanagan, K. \& Jupp, P.C., 2007, A sociology of spirituality, Ashgate, Surrey.

Flory, R.W. \& Miller, D.E., 2007, 'The embodied spirituality of the post-boomer Generations', in K. Flanagan \& P.C. Jupp (eds.), A Sociology of Spirituality, pp. 201-218, Ashgate, Aldershot.

Frost, M. \& Hirsch, A., 2003, The shape of things to come: Innovation and mission for the 21st-century church, Hendrickson, Peabody.

Gibbs, E., 2000, ChurchNext: Quantum changes in how we do ministry, InterVarsity, Downers Grove.

Guder, D.L., 1998, 'Missional structures: The particular community', in D.L. Guder (ed.), Missional church: A vision for the sending of the church in North America, pp. 221-247, Eerdmans, Grand Rapids.

Guder, D.L., 2000, The continuing conversion of the church, Eerdmans, Grand Rapids.

Hammet, E.H. \& Pierce, J.R., 2007, Reaching people under 40 while keeping people over 60: Being church for all generations, Chalice Press, St. Louis.

Harkness, A.G., 1998, 'Intergenerational education for an intergenerational church?', Religious Education 93(4), 43-59.

Harris, M., 1996, Proclaim jubilee: A spirituality for the twenty-first century, Westminster John Knox, Louisville.

Hilborn, D. \& Bird, M., 2002, God and the generations: Youth, age and the church today, Paternoster, London.

Kew, R., 2001, Brave new church: What the future holds, Morehouse, Harrisburg

Kitchens, J., 2003, The postmodern parish: New ministry for a new era, Alban Institute, Herndon.

Koester, H., 2004, 'Paul's proclamation of God's justice for the nations', Theology Digest 51(4), 303-314.

Kraft, C.H., 2005, Christianity in culture: A study in dynamic biblical theologizing in cross-cultural perspective, 25th edn., Orbis Books, Maryknoll. 
Leith, J.H., 1990, From generation to generation: The renewal of the church according to its own theology and practice, Westminster John Knox, Louisville.

Lohfink, G., 1984, Jesus and community, Fortress, Philadelphia.

Long, J., 1997, Generating hope: A strategy for reaching the postmodern generation, InterVarsity Press, Downers Grove.

Lynch, G., 2002, After religion: 'Generation X' and the search for meaning, Darton, Longman \& Todd, London.

MacIntyre, A., 1984, After virtue, 2nd edn., University of Notre Dame Press, Notre Dame.

McManus, E.R., 2001, An unstoppable force: Daring to become the church God had in mind, Group Publishing, Loveland.

Mead, L.B., 1991, The once and future church: Reinventing the congregation for a new mission frontier, The Alban Institute, Washington DC.

Merritt, C.H., 2007, Tribal church: Ministering to the missing generation, The Alban Institute, Herndon.

Moore, R., 2001, Friends: The key to reaching Generation X, Regal, Ventura.

Peterson, E.H., 1989, The contemplative pastor: Returning to the art of spiritual direction, Eerdmans, Grand Rapids.

Rawls, J., 1999, A theory of justice, rev. edn., Harvard University Press, Cambridge.

Rendle, G., 2002, The multigenerational congregation: Meeting the leadershipchallenge, AlbanInstitute, Bethesda.

Rouse, R. \& Van Gelder, C., 2008, A field guide for the missional congregation: Embarking on a journey of transformation, Augsburg Fortress, Minneapolis.

Schaller, L.E., 1999, Discontinuity and hope: Radical change and the path to the future, Abingdon, Nashville.

Shenk, W.R., 1995, Write the vision: The church renewed, Trinity Press International, Harrisburg.
Snyder, H.A., 1996, Radical renewal: The problem of wineskins today, Touch Publications, Houston.

Strauss, W. \& Howe, N., 1992, Generations: The history of America's future, 1584 to 2069, William Morrow, New York.

Thompson, G.B., 2003, Treasure in clay jars: New ways to understand your church, The Pilgrim Press, Cleveland.

Van Kooten, J. \& Barrett, L., 2004, 'Missional Authority', in L.Y. Barrett \& W.C. Hobbs (eds.), Treasure in clay jars: Patterns in missional faithfulness, pp. 139-148, Eerdmans, Grand Rapids.

Volf, M., 1996, Exclusion and embrace: A theological exploration of identity, otherness, and reconciliation, Abingdon, Nashville.

Volf, M., 2005, Free of charge: Giving and forgiving in a culture stripped of grace, Zondervan, Grand Rapids.

Weber, M., 1978, Economy and society: An outline of interpretive sociology, 2 vols, University of California Press, Berkeley.

Whitesel, B. \& Hunter, K.R., 2000, A house divided: Bridging the generation gaps in your church, Abingdon, Nashville.

Wright, C.J.H., 2006, The mission of God: Unlocking the Bible's grand narrative, InterVarsity Press, Downers Grove.

Wright, D.R. \& Creasy-Dean, K., 2004, 'Youth, passion, and intimacy in the context of koinonia', in D.R. Wright \& J. Kuentzel (eds.), Redemptive transformation in Practical Theology: Essays in honor of James E. Loder, Jr., pp. 153-188, Eerdmans, Grand Rapids.

Wuthnow, R., 2007, After the Baby Boomers: How twenty- and thirty-somethings are shaping the future of American religion, Princeton University Press, Princeton. 